\title{
Innovation in public-private partnerships (PPPs): the Spanish case of highway concessions
}

\section{Thais Rangel and Jesús Galende}

This article identifies the factors that determine innovation in transport PPPs in Spain. Innovation is an important way of achieving efficiency but it is not an intrinsic characteristic of PPP projects. The authors describe the multiple regression model they devised to estimate innovation. The results show that PPP contracts can be designed to maximize innovation in REDD. However, there does not appear to be greater innovation in any other areas. The information provided has important implications for public service organizations considering new contracts with the private sector.

Budgetary constraints, as well as the belief that the private sector can in some circumstances be more cost-efficient than the public sector, mean that governments worldwide are using publicprivate partnerships (PPPs) to construct and operate infrastructure. Innovation is an important factor that can enable the private sector to provide more cost-efficient services than the public sector (Spackman, 2002).

However, there are two schools of thought regarding the application of innovation in PPP contracts. Some academic studies show that the private sector is able to provide innovative solutions to delivering services and infrastructure (for example Spackman, 2002; Akintoye et al., 2003; Harris, 2004; Grimsey and Lewis, 2005). Other studies conclude that although a private contractor may promise to introduce innovations, this does not always happen (for example Ball et al., 2000; Parker and Hartley, 2003; Klijn and Teisman, 2003; Reeves, 2003; Fischbacher and Beaumont, 2003; Hurst and Reeves, 2004).

This article examines this dilemma by analysing the factors that behind innovative activities by the private sector in PPP contracts.

\section{Model and hypotheses}

Four main factors appear to influence innovation by PPPs:

- Type of risk assumed by the private sector.

- Transfer of design responsibility.

- Provision for penalties if the infrastructure does not meet the quality factors specified in the contract.

- Competition between bidders.
Type of risk assumed by the private sector

In any PPP contract, risks should be shared by the private and public sectors according to management skills and ability to control risks (Lemos et al., 2003; Harris, 2004). However, according to Parker and Hartley (2003), a large number of risks in PPP projects are managed better by the private sector. Transferred risks incentivize private sector contractors to maximize efficiency (Broadbent and Laughlin, 1999; Grimsey and Lewis, 2005). So the first hypothesis we investigated (H1) was whether the type of risk assumed by the private sector influences innovation in a PPP contract.

\section{Transfer of design responsibility}

Private financing generates new technological ideas for infrastructure design (for example see Spackman, 2002). According to Grimsey and Lewis (2005), the transfer of design responsibility to the private sector encourages it to explore the innovations that can improve quality and reduce operating expenses. Furthermore, Harris (2004) confirmed that PPPs work better when the private sector is involved in the design stage of the project. The second hypothesis, H2, we looked at was whether: 'The transfer of design responsibility to the private sector determines the application of innovation in a PPP contract'.

\section{Penalties}

Since the private sector partner is remunerated by government only if the services delivered are acceptable, the private sector is motivated to provide good work, deliver the service within the agreed period of time and to save costs
Thais Rangel is a PhD student in the Transport Research Centre, Polytechnic

University of

Madrid, Spain.

Jesús Galende is

Professor in the

Department of

Business

Administration and

Management,

University of

Salamanca, Spain. 
without sacrificing the quality. According to Vassallo (2007), the Spanish Public Works Concession Law 2003, which established the introduction of bonuses and penalties related to the fulfilment of certain quality requirements, has had a major effect on the outcomes of PPP projects. The contracting terms must include mechanisms to encourage the bidder to provide the highest possible level of service, so that improvements in efficiency are transferred to the users. If the contractor fails to meet minimum standards, the public authority will penalize the contractor or cancel the contract. Hence our third hypothesis, H3: 'Provisions for penalties in the PPP contract determine the application of innovation in a contract if the infrastructure does not meet the quality factors'.

\section{Competition}

There is a greater probability of reaching optimum efficiency when there is competition between companies in the procurement process (Ball et al., 2000; Akintoye et al., 2003; Grimsey and Lewis, 2005). Competition encourages innovative companies to reduce costs, and hence, the charges to the public sector. The fourth hypothesis we tested was therefore: 'Competition between bidders to carry out a PPP project determines the application of innovation in a PPP contract' (H4).

\section{Methodology}

The data we used to test our hypotheses was from highway concessions (PPP contracts) awarded to Spanish companies. An electronic questionnaire was produced with the Spanish Association of Construction Companies (SEOPAN) and sent to the nine Spanish companies that have PPP agreements with the Spanish government, as well as with governments from countries in Africa and Latin America.

There is no comprehensive database of the organizations in Spain that are involved in PPP projects. Few companies have this type of contract owing to the large investment necessary which means that the overall number of organizations involved can be limited. (The journal, Public Works Financing, publishes a world-wide ranking of financing and private management of infrastructure annually. In 2004, seven of the 10 top companies were Spanish companies; all of these are included in this article.)

The questionnaire was sent to the concessions director of the companies. Six companies responded. A total of 79 contracts were reported on; 11 of these contracts were not valid for our research because they did not correspond with our period of study. Therefore, this article includes 68 highway concessions in Spain operating between 1996 and 2005 .

The aim of the study is to quantify the impact of our four hypotheses about factors relating to innovation in PPP projects. A full description of the factors and innovation are given in table 1 . Innovation can be measured quantitatively or qualitatively. Both measures have advantages and disadvantages and there is no consensus about which is the best. Our measures are based on the recommendations of the Organization for Economic Co-operation and Development (OECD) manuals: the Frascati Manual, for analysing R\&D activities, and the Oslo Manual, for analysing other innovative activities. The Frascati Manual states that ' $\mathrm{R} \& \mathrm{D}$ activities include creative work undertaken on a systematic basis in order to increase the stock of knowledge, including knowledge of man, culture and society, and the use of this stock of knowledge to devise new applications' (OECD, 2002, p. 30). R\&D activities in the public works sector include creating new applications for traffic control: including providing information to users, tolls and guaranteeing safety, quality and comfort.

The Oslo Manual states that innovation is the implementation of a new or significantly improved product (good or service), or process, a new marketing method, or a new organizational method in business practices, workplace organization or external relations' (OECD, 2005, p. 46). Innovative activities in this case include industrial engineering or industrial design, commercial innovation or organizational innovation.

The characteristics of each measure of innovation are included in table 2.

Initially a factor analysis (component analysis) was applied for the dependent variable 'innovation' and the independent variables 'risk' and 'penalty'. Our purpose was to identify factors that explain the variables with a minimal loss of information. Subsequently, and with the aim of verifying whether the proposed factors determine innovation in PPPs, a multiple regression analysis was applied. This technique allowed us to explain a dependent variable by means of the values of several independent variables. The relative importance of each explanatory variable for the dependent variable was determined (amount and direction), together with the relationships between the independent variables.

\section{Results}

For the purpose of verifying the suitability of factor analysis, Bartlett and Kaiser-Meyer-Olkin (KMO) tests were carried out for each variable. 
Table 1. Factors affecting innovation.

\begin{tabular}{|c|c|c|c|}
\hline Name & Variable & Definition & Scale \\
\hline Private sector risk & $\begin{array}{l}\text { CONRISK } \\
\text { FINRISK } \\
\text { OPERISK } \\
\text { RELRISK } \\
\text { DEMRISK } \\
\text { ENVRISK }\end{array}$ & $\begin{array}{l}\text { Construction risk } \\
\text { Financial risk } \\
\text { Operational risk } \\
\text { Relations between public and private sectors risk } \\
\text { Demand risk } \\
\text { Environmental risk }\end{array}$ & $\begin{array}{l}\text { Ordinal } \\
\text { Ordinal } \\
\text { Ordinal } \\
\text { Ordinal } \\
\text { Ordinal } \\
\text { Ordinal }\end{array}$ \\
\hline $\begin{array}{l}\text { Transfer of design } \\
\text { responsibility }\end{array}$ & DESRISK & Design risk & Ordinal \\
\hline Provision for penalties & $\begin{array}{l}\text { QUAPEN } \\
\text { DESPEN } \\
\text { DELPEN } \\
\text { ENVPEN }\end{array}$ & $\begin{array}{l}\text { Quality penalty } \\
\text { Design penalty } \\
\text { Delay in the building work penalty } \\
\text { Environment penalty }\end{array}$ & $\begin{array}{l}\text { Ordinal } \\
\text { Ordinal } \\
\text { Ordinal } \\
\text { Ordinal }\end{array}$ \\
\hline $\begin{array}{l}\text { Competition between } \\
\text { bidders }\end{array}$ & NUMBID & Number of companies bidding for the public contract & Metric \\
\hline Innovation & $\begin{array}{l}\text { RDEXP } \\
\text { INNEXP } \\
\text { RDPERS } \\
\text { INNPERS } \\
\text { INNPROD } \\
\text { INNPROC }\end{array}$ & $\begin{array}{l}\text { R\&D expenditures (\% sales) } \\
\text { Other innovative activities expenditures (\% sales) } \\
\text { Number of working hours in R\&D (\% total working hours) } \\
\text { Number of working hours in other innovative activities } \\
\text { (\% total working hours) } \\
\text { Number of product innovations } \\
\text { Number of process innovations }\end{array}$ & $\begin{array}{l}\text { Metric } \\
\text { Metric } \\
\text { Metric } \\
\text { Metric } \\
\text { Metric } \\
\text { Metric }\end{array}$ \\
\hline
\end{tabular}

Table 2. Characteristics of the measures of innovation.

\begin{tabular}{ll}
\hline Measure & Characteristics \\
\hline Innovative activities expenditures (\% sales) & $\begin{array}{l}\text { Measure of the financial investment } \\
\text { More objectivity than number of innovations }\end{array}$ \\
$\begin{array}{l}\text { Number of working hours in innovative } \\
\text { activities (\% total working hours) }\end{array}$ & $\begin{array}{l}\text { Measure of human resources } \\
\text { Weighting is possible } \\
\text { More objectivity than number of innovations } \\
\text { Measure of tacit knowledge }\end{array}$ \\
Number of innovations & $\begin{array}{l}\text { Measure of marketed innovations } \\
\text { It is possible to account for the sales of new products } \\
\text { Measure of the final result of the innovation }\end{array}$
\end{tabular}

For the variable 'innovation', Bartlett's test had an approximate chi square value of 378,903 and KMO 0.606. For the variable 'penalty', Bartlett's test had an approximate chi square value of 255,832 and KMO 0.766. Finally, the variable 'risk' had an approximate chi square value of 107,358 and KMO 0.672. These results allow us to conclude that the information is appropriate for the performance of factor analysis.

As can be seen in table 3 , three factors were extracted for innovation, with a total explained variance of 92.94\%: 'other innovative activities', 'R\&D activities' and 'number of innovations'. Regarding the type of risk assumed by the private sector, a single factor was obtained, 'type of risk', which explains $63.12 \%$ of the total variance. This factor includes different risks assumed by the private sector such as construction risk (for example the quality and duration of the work, insolvency of suppliers and construction costs overrun), financial risk of the project (inflation rate volatility, availability of finance and high finance cost), operational risk (low operating productivity and maintenance costs higher than expected) and demand risk. In the analysis of penalties, only one factor was obtained, 'penalty', which explains $82.89 \%$ of the total variance. It includes different penalties if the private contractor does not meet the minimum requirements for quality, design, duration of the work and environmental conditions agreed in the contract. The numbers of factors were calculated by means of the latent root criterion. For the analysis of the reliability of all the analyses, Cronbach's alpha coefficient was calculated, obtaining in all cases values higher than the minimal allowed 0.6. Therefore the internal consistency of each one of the factors was ratified.

Multiple regression analysis was applied to verify and to quantify whether the factors proposed in our model are determinants of 
Table 3. Final variables extracted from factor analysis.

\begin{tabular}{|c|c|c|}
\hline Variable & Name & Description (original variables) \\
\hline INNACT & Other innovative activities & $\begin{array}{l}\text { Other innovative activities expenditures } \\
\text { Number of working hours in other innovative activities }\end{array}$ \\
\hline RDACT & R\&D activities & $\begin{array}{l}\text { R\&D expenditures } \\
\text { Number of working hours in } R \& D\end{array}$ \\
\hline INN & Number of innovations & $\begin{array}{l}\text { Number of product innovations } \\
\text { Number of process innovations }\end{array}$ \\
\hline RISK & Type of risk & $\begin{array}{l}\text { Construction risk } \\
\text { Financial risk } \\
\text { Operational risk } \\
\text { Demand risk }\end{array}$ \\
\hline PENALTY & Penalty & $\begin{array}{l}\text { Quality penalty } \\
\text { Design penalty } \\
\text { Environment penalty } \\
\text { Delay in the building work penalty }\end{array}$ \\
\hline
\end{tabular}

innovation in PPP projects. The correlations between the independent variables were low. A more important correlation exists between RISK and DESRISK. They are included in our article because others authors consider them to be important factors and it is interesting to find out how they feature in Spanish companies. The tolerance index and the variance inflation factors (VIF) were examined. No significant multi-collinearity problems were found between the independent variables.

Three multiple regression analyses were carried out, and the results are shown in table 4. The dependent variable of model $1(\mathrm{R} \& \mathrm{D}$ activities) has a significantly high relationship $(74.20 \%)$. All the variables were significant,

Table 4. Results for multiple regressions.

\begin{tabular}{llcc}
\hline Innovation & Variables & Coefficients & T-value \\
\hline RDACT & Constant & -10.167 & $-5.178^{*}$ \\
(model 1) & RISK & 0.724 & $5.478^{*}$ \\
& DESRISK & 0.211 & 0.601 \\
& PENALTY & 0.514 & $4.084^{*}$ \\
& NUMBID & 0.708 & $8.608^{*}$ \\
& $\mathrm{R}^{2}$ & 0.742 & \\
& Adjusted R & 0.725 & \\
INNACT & F value & $45.261^{*}$ & -0.285 \\
(model 2) & Constant & -0.561 & 0.592 \\
& RISK & 0.079 & 0.709 \\
& DESRISK & 0.250 & 0.271 \\
& PENALTY & 0.034 & -1.529 \\
& NUMBID & -0.126 & \\
& R & 0.059 & $2.596^{* *}$ \\
INN & Adjusted R & 0.000 & 1.111 \\
(model 3) & F value & 0.992 & -0.924 \\
& Constant & 2.453 & $-2.478^{* *}$ \\
& RISK & 0.071 & -1.159 \\
& DESRISK & -0.156 & \\
& PENALTY & -0.150 & \\
& NUMBID & -0.063 & \\
& R & \\
& Adjusted R & & \\
& F value & 0.165 & $3.115 * *$ \\
\hline
\end{tabular}

$* p<0.01 ; * * p<0.05$ with the exception of the transfer of design responsibility. This result supports the general proposition that innovation is not an intrinsic characteristic of PPP projects, but there are factors that determine the introduction of innovation by the private sector in these projects. Therefore, results show a relationship between R\&D activities in PPP projects and three factors: type of risk assumed by the private sector, provisions for penalties against the private contractor and competition between bidders.

The dependent variable of model 2 (other innovative activities) is not significant. These results allow us to conclude that PPPs can be more related to $\mathrm{R} \& \mathrm{D}$ activities. The dependent variable of model 3 is the number of innovations, as consequence of both $\mathrm{R} \& \mathrm{D}$ activities and other innovative activities. Only the variable 'penalty' was significant at a 0.05 level.

The variable 'type of risk' is significant at 0.01 in model 1 . This result indicates that the type of risk assumed by the private sector is a determinant of $\mathrm{R} \& \mathrm{D}$ activities in PPP projects. The construction, financial, operational and demand risks assumed by the private sector can affect the innovative activity of the private contractor. Although the result supports the first hypothesis ( $\mathrm{H} 1)$, it is necessary to take into account that this hypothesis can only be proved for R\&D activities.

The variable 'transfer of design responsibility' is not significant in any case. In other words, it does not have a significant relationship with innovation in PPP projects. The second hypothesis (H2) is not accepted. This might be explained by the fact that part of the explanation of design risk is inside the general risk. There is a certain correlation between both variables as has been mentioned 
previously.

The variable 'penalty' is also significant at 0.01 in model 1 . The provision for penalties affects the progress of $\mathrm{R} \& \mathrm{D}$ activities in PPP projects. This result indicates that the third hypothesis can be confirmed, although only for the case of R\&D activities (it is not significant in model 2). In model 3, the variable 'penalty' is also significant, but not with the expected relationship: in fact, it is negative. The result indicates that the provision for penalties is positively related to a preliminary effort to carry out R\&D activities in PPP projects, but this relationship does not result in new technologies. The variable 'number of innovations' includes both R\&D activities and other innovative activities, hence the results obtained in model 3 may not be comparable to model 1 (which only includes R\&D activities) and to model 2 (which only includes other innovative activities). In other words, model 3 is the combination of models 1 and 2, although it uses measurements of results and not of innovative effort.

The results may indicate that although a private contractor will make an effort to invest in $\mathrm{R} \& \mathrm{D}$ activities, this effort materializes in more conservative performances which do not entail radical innovation. The purpose of the private contractor is to make sure that the quality of the work is simply that specified in the contract. The generation of major innovations could, in case of failure, risk the outcome of the quality required in the PPP contract, which may result in a penalty.

The variable 'competition between bidders' is significant at 0.01 in model 1 indicating that the competition and rivalry among companies can affect $\mathrm{R} \& \mathrm{D}$ activities in PPP projects. The bidders seek to propose profitable innovative projects to the government. A competitive market between bidders will ensure that the best option will be selected. The results support the fourth hypothesis, but only in the case of R\&D activities.

Although Ball et al. (2000) and Lemos et al. (2003) conclude that innovation is limited in PPP projects, our results indicate that, distinguishing between R\&D activities and other innovative activities, $\mathrm{R} \& \mathrm{D}$ activities do influence PPP projects.

\section{Conclusions}

A government will sign a PPP contract if it believes that the private sector will provide more efficient services than the public sector. Innovation activities are an important way of achieving efficiency. However, there is contradictory evidence in the academic literature about the existence of a relationship between PPPs and innovation-it is not an intrinsic characteristic of PPP projects but it is an important feature to have. This article has made an important contribution by investigating the determinant factors that can influence the innovative process in a PPP contract.

We produced a model to look at four characteristics in PPP contracts that might determine whether innovation activities are carried out by private contractor: type of risk assumed by the private sector; transfer of design responsibility; provision for penalties against the private contractor if the infrastructure does not meet the quality requirements specified in the contract; competition between bidders. The model was applied to a sample of 68 highway concessions in Spain (PPP contracts) between 1996 and 2005. They are companies with an important international presence, especially in Africa and Latin America.

The results show a significant relationship between three characteristics of PPPs and R\&D activities. The first factor is the type of risk assumed by the private sector. This risk can be related to quality problems, supply insolvency, increase of financial costs, reduction in productivity, demand problems and so on. If this risk is assumed by the private sector, the market mechanism generates the need for investment in finding new ways to manage possible contingencies.

A market mechanism appears again if there are a large number of companies bidding for the public contract. This is the second factor. Applying innovative methods and techniques, based on $\mathrm{R} \& \mathrm{D}$ activities, will give a competitive advantage.

The third factor is the existence of penalties if there are quality, design, delay or environmental problems. The presence of penalties is a sufficient motivation to encourage $\mathrm{R} \& \mathrm{D}$ activities by companies-it is unnecessary to actually apply the penalties. The outcome of a contract may influence future contracts.

Designing a PPP project with these characteristics will result in companies putting major efforts into $\mathrm{R} \& \mathrm{D}$ activities. This is important for governments to know.

We do not know whether these characteristics have influence on other types of innovative activities, such as commercial or organizational innovation. This is because the information available to us is limited by he fact that the topic of innovation in PPP projects is very new and there are few companies who 
have this type of contract because of the large investment required. Also we have only analysed highway concessions. It would be interesting to test the consistency of the results by analysing other types of contracts, such as schools, hospitals or prisons.

Despite these limitations, we believe that our findings are significant because there have been very few studies analysing innovation in PPPs. Of the few that exist none of them focused on explaining directly the impact of the factors that can determine innovation in PPPs. Moreover, all of the articles are basically case studies, whereas our article is a more objective statistical analysis.

The results also have important implications for management. PPP projects encourage innovative activities, specifically R\&D activities. This allows companies to sign important contracts with the government. Furthermore not only can technology be transferred but it can help companies achieve important synergies within their own organization.

An interesting future topic of research could be to analyse the influence of other factors such as public incentives and requirements useful in the procurement process and also innovation and quality in PPP projects.

\section{Acknowledgements}

This study was carried out within the framework of research project SEJ2007-63879/ECON, financed by the Dirección General de Investigación del Ministerio de Educación y Ciencia (State Office for Research of the Spanish Ministry of Education and Science) and by FEDER funds. The authors would like to thank the Spanish PPP concessionaires for providing the data used in this article but want to remain anonymous. The authors are also grateful to two anonymous referees for their invaluable comments.

\section{References}

Akintoye, A., Hardcastle, C., Beck, M. and Chinyio, E. (2003), Achieving best value in Private Finance Initiative project procurement. Construction Management and Economics, 21, pp. 461-470.

Ball, R., Heafey, M., King, D. (2000), Managing and concluding the PFI process for a new high school. Public Management, 2, pp. 159-179.

Broadbent, J. and Laughlin, R. (1999), The Private Finance Initiative: clarification of a future research agenda. Financial Accountability E Management, 15, pp. 95-115.

Fischbacher, M. and Beaumont, P. B. (2003), PFI, public-private partnerships and the neglected importance of process. Public Money E Management, 23, 3, pp. 171-176.

Grimsey, D. and Lewis, M. K. (2005), Are public private partnerships value for money? Accounting Forum, 29, pp. 345-378.

Harris, S. (2004), Public private partnerships: delivering better infrastructure services. Working paper (Inter-American Development Bank, Washington, D.C.).

Hurst, C. and Reeves, E. (2004), An economic of Ireland's first public private partnership. International Journal of Public Sector Management, 17, pp. 379-388.

Klijn, E. and Teisman, G. R. (2003), Institutional and strategic barriers to public-private partnership: an analyses of Dutch cases. Public Money E Management, 23, 3, pp. 137-146.

Lemos, T., Almeida, L., Betts, M. and Eaton, D. (2003), An examination on the sustainable competitive advantage of Private Finance Initiative projects. Construction Innovation, 3, pp. 249-259.

OECD (2002), OECD Proposed Standard Practice for Surveys of Research and Experimental Development_Frascati Manual (Paris).

OECD (2005), OECD Guidelines for Collecting and Interpreting Innovation Data-Oslo Manual (Paris).

Parker, D. and Hartley, K. (2003), Transaction costs, relational contracting and public private partnerships: a case study of UK defence. Journal of Purchasing and Supply Management, 9 , pp. 97-108.

Reeves, E. (2003), Public-private partnerships in Ireland: policy and practice. Public Money $\xi^{\circ}$ Management, 23, 3, pp. 163-170.

Spackman, M. (2002), Public-private partnerships: lessons from the British approach. Economic Systems, 26, pp. 283-301.

Vassallo, J. M. (2007), Implementation of quality criteria in tendering and regulating infrastructure management contracts. Journal of Construction Engineering and Management, 8, pp. 553-561. 